\title{
Variation in the Ureide Content of Jack Bean during the Reproductive Stages in Response to Nitrate
}

\author{
Liliane Santos Camargos ${ }^{1}$, Leandro Ferreira Aguiar $^{1}$, José Antônio Carmezini ${ }^{2}$ and \\ Ricardo Antunes Azevedo ${ }^{2 *}$ \\ ${ }^{I}$ Departamento de Ciências Naturais; Universidade Federal de Mato Grosso do Sul; 79600-000; Três Lagoas - MS \\ - Brasil. ${ }^{2}$ Departamento de Genética; Escola Superior de Agricultura Luiz de Queiroz; Universidade de São Paulo; \\ 13418-900; Piracicaba - SP - Brasil
}

\begin{abstract}
Nitrogen is frequently the limiting mineral nutrient for plant productivity and it is essential to obtain an understanding of how this element is assimilated and its metabolism regulated, in crop plants. The objective of this work was to study nitrogen metabolism in the tropical legume Canavalia ensiformis, a plant species used as a green manure. The nitrate dose provided changed the concentrations of ureides exported via the xylem, whilst the developmental stage alterations demonstrated to influence the form of ureide exported via the xylem. Considering the content of ureides as an indicator of $N$-fixation status, it could be concluded that $N$-fixation was affected in the presence of nitrate in $\mathrm{C}$. ensiformis.
\end{abstract}

Key words: Nitrogen metabolism, allantoin, allantoic acid, Canavalia ensiformis, ureides

\section{INTRODUCTION}

Mineral nutrition is essential for plant growth (Medici et al., 2004; 2005; Garcia et al., 2006; Oroka and Omoregie, 2007); nitrogen is frequently the limiting mineral nutrient for plant productivity (Gaiad et al., 2006; Lea and Azevedo, 2006) and it is important in animal nutrition (Huaynate et al., 2006). On the other hand, it is important to note that the production of nitrogenous waste by livestock agriculture is a significant environmental concern in terms of pollution of land and water (Kingston-Smith et al., 2006). Amino acids are the most important compounds that contain nitrogen (Azevedo et al., 2006; Ferreira et al., 2006; Pompeu et al., 2006; Landry and Delhaye, 2007; Lea and Azevedo, 2007; Varisi et al., 2007) and are incorporated into proteins, which are extremely important for plant metabolism and in the diet of animals (Azevedo et al., 1997; 2004; Brennecke et al., 1996; Santos et al., 2006). Plants acquire nitrogen from the soil mainly in the form of nitrate, which in order to be utilized must be reduced to ammonia by the enzymes nitrate reductase and nitrite reductase to be assimilated by the glutamine synthetase/glutamate synthase system (GS/GOGAT) (Medici et al., 2003; Lea and Azevedo, 2006; 2007). In tropical legumes, when ammonia is derived from nitrogen fixation in the symbiotic nodule association, the nitrogen products exported by the root system via the xylem are manly ureides (do Amarante et al., 2006). However, when ammonia is formed by assimilatory nitrate reduction, the products exported are mainly the amino acid amides asparagine and glutamine (Lea and Azevedo,

\footnotetext{
*Author for correspondence: ricardo.azevedo@pq.cnpq.br
} 
2006). In plants the ureides allantoin and allantoic acid are formed in purine metabolism, and in some legumes both compounds play an important role as nitrogen sources (Filippi et al., 2007). Asparagine also plays an important role in nitrogen storage and transport (Lea et al., 2007). In previous work on C. ensiformis, Camargos et al. (2004) observed that the distribution of amino acids in different tissues and organs was dictated by the developmental age of the plant.

The objective of this work was to study changes in ureide metabolism during the reproductive period of $C$. ensiformis, in response to nitrate.

\section{MATERIAL AND METHODS}

Commercial seeds of C. ensiformis (L.) D.C. (Jack bean), were provided by Piraí Sementes (Piracicaba, SP). The seeds were germinated in filter paper rolls with the bottom immersed in water. The seedlings were transferred to $4 \mathrm{~L}$ pots containing vermiculite and maintained in a glasshouse at temperatures from 25 to $30^{\circ} \mathrm{C}$, under natural daylight conditions, where the maximum light intensity reached $2050 \mu \mathrm{mol} \mathrm{m} \mathrm{m}^{-2} \mathrm{~s}^{-1}$ around midday, at the Genetics Department/ESALQ/USP. The plants were maintained for 100 days, supplied with Hoagland's nutritive solution, without nitrate $\left(\mathrm{T}_{0}\right)$, with $7.5 \mathrm{mM}$ nitrate $\left(\mathrm{T}_{1}\right)$, and $15 \mathrm{mM}$ nitrate $\left(\mathrm{T}_{2}\right)$, change regularly (every 4 days). The $\mathrm{T}_{0}$ treatment was inoculated with a commercial inoculant. Three replicates were analyzed for each developmental stage (onset of flowering [S1] and fruiting stage [S2]). Roots, leaves, and stems were collected and placed directly into liquid nitrogen, at about 10:30 a.m., and were then maintained at $80^{\circ} \mathrm{C}$ for later analyses. The xylem sap was collected by exudation for one hour (between 10:00 and 11:00 a.m.) and stored at $-80^{\circ} \mathrm{C}$ for further analyses.

The extraction of total ureides (allantoin and allantoic acid) was carried out as described by Vogels and Van Der Drift (1970) using allantoin as a standard. Nitrate was determined by the method of Camargos et al. (2006).

A complete randomized experimental design was used with three replications. The quantitative analyses data, for the same parameter and at the same developmental stage, were submitted to analysis of variance and the means were compared by Tukey test at $5 \%$ significance.

\section{RESULTS AND DISCUSSION}

At the onset of flowering (S1) of $C$. ensiformis, a significant increase in nitrate concentration was observed in all the organs analyzed (leaves, stems, and roots), as a consequence of increasing nitrate in the nutrient solution (Table 1). Perin et al. (2004) demonstrated that in Crotalaria juncea, an increased supply of nutrients led to nitrogen accumulation and increased biomass. Stress conditions that impair $\mathrm{N}$ assimilation in several distinct plant species, including legume species of both ureide- and amide-exporting categories, have been shown to lead to specific changes in the amino acid composition of the xylem (do Amarante et al., 2006). Excess nitrogen supply has also been shown to induce high levels of oxidative stress in maize roots (Medici et al., 2004). In $C$. ensiformis, the nitrate levels in organs seemed to be influenced linearly by the nitrate dose supplied, without indication of any pattern with regard to changes in development, since nitrate goes up dramatically from $T_{0}$ to $T_{2}$ in all organs in $S 1$, but goes down from $T_{1}$ to $T_{2}$ in $S 2$ (Table 1).

At the $\mathrm{S} 1$ stage of development of $C$. ensiformis, the total concentrations of ureides (allantoin + allantoic acid) in plants that received nitrate in solution were higher than those reported by Camargos et al. (2006) for the plants at the vegetative stage. This behavior was also reported by Peoples et al. (1991) in three species of the genus Arachis. The total amounts of ureides in $\mathrm{T}_{1}$ and $\mathrm{T}_{2}$ were similar to those reported by Atkins et al. (1992) for soybean tissues, under conditions in which the plants were not fixing nitrogen symbiotically. Herridge et al. (1996) reported the presence of ureides in the xylem sap and in an extract of stem tissues of Acacia mearnsii, whereas in Gliricidia sepium and Sesbania grandiflora, these authors observed high concentrations of ureides in the sap, but not in stems. Ureides have been observed in unnodulated plants and in non-nitrogen-fixing species, contradicting the frequent idea that ureides are direct products of nitrogen fixation. In $C$. ensiformis the ureide concentrations in organs and xylem sap of plants that received nitrate (Tables 1 and 2 , respectively) were higher than the concentrations observed by Herridge et al. (1996) for arboreal species. Although some of the values observed for allantoin and allantoic acid in all organs in S1 and S2 were not statistically different, overall there was a clear decrease trend in $\mathrm{T}_{1}$ and 
$\mathrm{T}_{2}$ in relation to $\mathrm{T}_{0}$ (Table 1). Peoples et al. (1991) observed an increase in the levels of ureides owing to the beginning of the reproductive period in Arachis species and soybean plants, which allowed to correlate the results obtained in this work with developmental stage of the plant, but with reduction in ureides concentration. The values obtained for ureides were higher than those reported by Atkins et al. (1992) and Herridge et al. (1996) for plants that received nitrate, suggesting that $C$. ensiformis had a ureide metabolism with lower sensitivity to nitrate exposure than the species studied by Atkins et al. (1992) and Herridge et al. (1996), even though the levels observed here showed reduction in respect to nitrate. Therefore, the reduction observed in relation to $T_{0}$ was not the same observed when $T_{1}$ and $\mathrm{T}_{2}$ were compared, which appeared to indicate that symbiotic fixation was very sensitive to nitrate in $C$. ensiformis, with very little difference between $T_{1}$ and $T_{2}$, but a significant difference between the $T_{1}$ and $T_{2}$ in relation to $T_{0}$.

In xylem sap the highest ureide concentrations translocated via the xylem were in the form of allantoin. In S1, there was a higher concentrations of allantoin in the xylem sap of $\mathrm{T}_{2}$ plants when compared to $\mathrm{T}_{1}$ (Table 2). However, the reductions in total ureide levels were significant in the xylem sap sampled from $\mathrm{T} 1$ and $\mathrm{T} 2$ plants when compared with $\mathrm{T}_{0}$. In $\mathrm{S} 2, \mathrm{~T}_{1}$ exhibited a higher allantoin content when compared to $\mathrm{T}_{2}$, whilst the variations obtained for allantoic acid were not significant between $T_{1}$ and $T_{2}$, and the values were similar to those observed for Desmodium rensonii and soybean (Peoples et al., 1992; Atkins et al., 1992; Herridge et al., 1996). In C. ensiformis, it was observed that there was not a direct correlation between the amount of nitrate supplied to the plant and the concentrations of ureides present both in the xylem sap (Table 2) and in the organs (Table 1). There is considerable variation in the ureide data for xylem sap with regard to allantoin for $T_{1}$ and $T_{2}$ treatments, as the $T_{2}$ nitrate treatment produced the highest allantoin concentration in $\mathrm{S} 1$, whereas $\mathrm{T}_{1}$ produced the highest concentrations of allantoin in S2, (Table 2). Therefore, this behavior does not allow a relationship between the reduction in ureide levels and the supplied nitrate concentration to be established. Considering the level of ureides as an indicator of $\mathrm{N}$-fixation status, it was possible to say that $\mathrm{N}$-fixation is likely to have been affected in the presence of nitrate in $C$. ensiformis.

Table 1 - Quantitative analysis of nitrate and ureides in Canavalia ensiformis organs during the reproductive stage ${ }^{(1)}$

\begin{tabular}{|c|c|c|c|c|c|c|}
\hline \multirow[t]{2}{*}{ Treatment } & \multicolumn{2}{|c|}{$\begin{array}{l}\text { Nitrate } \\
\text { mmol/g fresh weight }\end{array}$} & \multicolumn{2}{|c|}{$\begin{array}{l}\text { Allantoin } \\
\text { nmol/g fresh weight }\end{array}$} & \multicolumn{2}{|c|}{$\begin{array}{l}\text { Allantoic acid } \\
\text { nmol/g fresh weight }\end{array}$} \\
\hline & S1 & S2 & S1 & S2 & S1 & S2 \\
\hline \multicolumn{7}{|l|}{ Leaves } \\
\hline $\mathrm{T}_{0}$ & $1.19 \mathrm{C}$ & $1.39 \mathrm{C}$ & $1593.0 \mathrm{~A}$ & $1781.7 \mathrm{~A}$ & $1294.0 \mathrm{~A}$ & $1623.9 \mathrm{~A}$ \\
\hline $\mathrm{T}_{1}$ & $9.23 \mathrm{~B}$ & $5.27 \mathrm{~A}$ & $294.3 \mathrm{~B}$ & $159.6 \mathrm{~B}$ & $241.4 \mathrm{~B}$ & $553.2 \mathrm{AB}$ \\
\hline $\mathrm{T}_{2}$ & $19.02 \mathrm{~A}$ & $3.49 \mathrm{~B}$ & $364.0 \mathrm{AB}$ & $216.5 \mathrm{AB}$ & $247.6 \mathrm{~B}$ & $259.4 \mathrm{~B}$ \\
\hline$\overline{\mathrm{CV}(\%)}$ & 3.8 & 8.6 & 0.2 & 0.3 & 1.0 & 3.6 \\
\hline \multicolumn{7}{|l|}{ Stems } \\
\hline $\mathrm{T}_{0}$ & $0.93 \mathrm{C}$ & $0.15 \mathrm{C}$ & $1540.0 \mathrm{~A}$ & $730.0 \mathrm{~A}$ & $437.0 \mathrm{~A}$ & $1560.0 \mathrm{~A}$ \\
\hline $\mathrm{T}_{1}$ & $9.57 \mathrm{~B}$ & $16.42 \mathrm{~A}$ & $352.4 \mathrm{~B}$ & $511.3 \mathrm{~A}$ & $104.6 \mathrm{AB}$ & $123.9 \mathrm{~B}$ \\
\hline $\mathrm{T}_{2}$ & $35.75 \mathrm{~A}$ & $7.45 \mathrm{~B}$ & $462.1 \mathrm{AB}$ & $151.1 \mathrm{~B}$ & $63.6 \mathrm{~B}$ & $226.4 \mathrm{AB}$ \\
\hline $\mathrm{CV}(\%)$ & 1.8 & 4.2 & 0.1 & 4.9 & 0.8 & 0.3 \\
\hline \multicolumn{7}{|l|}{ Roots } \\
\hline $\mathrm{T}_{0}$ & $0.04 \mathrm{C}$ & $0.81 \mathrm{C}$ & $1090.9 \mathrm{~A}$ & $524.0 \mathrm{~A}$ & $517.5 \mathrm{~A}$ & $1607.6 \mathrm{~A}$ \\
\hline $\mathrm{T}_{1}$ & $9.38 \mathrm{~B}$ & $5.37 \mathrm{~A}$ & $267.8 \mathrm{~B}$ & $95.6 \mathrm{~B}$ & $229.0 \mathrm{~B}$ & $662.8 \mathrm{~B}$ \\
\hline $\mathrm{T}_{2}$ & $91.67 \mathrm{~A}$ & $5.82 \mathrm{~A}$ & $281.5 \mathrm{~B}$ & $89.7 \mathrm{~B}$ & $275.9 \mathrm{~B}$ & 798.0 AB \\
\hline $\mathrm{CV}(\%)$ & 1.7 & 4.6 & 0.2 & 1.7 & 6.2 & 0.2 \\
\hline
\end{tabular}


Table 2 - Quantitative analysis of ureides ${ }^{(1)}$ in the xylem sap of Canavalia ensiformis during the reproductive stage

\begin{tabular}{|c|c|c|c|c|c|c|}
\hline \multirow[t]{2}{*}{ Treatment } & \multicolumn{2}{|c|}{ Allantoin (nmol/mL) } & \multicolumn{2}{|c|}{ Allantoic acid (nmol/mL) } & \multicolumn{2}{|c|}{ Total ureides $(\mathrm{nmol} / \mathrm{mL})$} \\
\hline & S1 & S2 & $\overline{\text { S1 }}$ & S2 & $\overline{\text { S1 }}$ & S2 \\
\hline $\mathrm{T}_{0}$ & $893.3 \mathrm{~A}$ & $767.0 \mathrm{~A}$ & $932.0 \mathrm{~A}$ & $564.0 \mathrm{~A}$ & $1825.3 \mathrm{~A}$ & $1331.0 \mathrm{~A}$ \\
\hline $\mathrm{T}_{1}$ & $119.9 \mathrm{~B}$ & $199.6 \mathrm{AB}$ & $70.9 \mathrm{~B}$ & $34.8 \mathrm{~B}$ & $190.8 \mathrm{~B}$ & $234.4 \mathrm{~B}$ \\
\hline $\mathrm{T}_{2}$ & $209.8 \mathrm{AB}$ & $66.0 \mathrm{~B}$ & $86.9 \mathrm{~B}$ & $50.8 \mathrm{~B}$ & 296.7 B & $116.8 \mathrm{~B}$ \\
\hline $\mathrm{CV}(\%)$ & 0.4 & 0.8 & 1.0 & 1.1 & 0.2 & 0.4 \\
\hline
\end{tabular}

${ }^{\text {(1) }}$ S1: onset of flowering; $\mathrm{S} 2$ : fruiting stage; $\mathrm{T}_{0}$ : without $\mathrm{NO}_{3}{ }^{-} ; \mathrm{T}_{1}$ : with $7.5 \mathrm{mM} \mathrm{NO}_{3}^{-} ; \mathrm{T}_{2}$ : with $15 \mathrm{mM} \mathrm{NO}_{3}^{-}$. Values represent means of three replicates. Values for the same stage sharing the same letter did not differ significantly at 5\% (Tukey test)

\section{CONCLUSION}

The nitrate doses supplied induced significant reduction in the concentrations of total ureides exported via the xylem and in all organs tested, whilst changes in developmental stage influenced the form of ureide exported via the xylem.

\section{RESUMO}

Nitrogênio é o nutriente mineral mais limitante e importante para produção vegetal e o entendimento de como esse elemento é assimilado e como seu metabolismo é regulado, são essenciais para plantas cultivadas. O objetivo deste trabalho foi estudar as variações no metabolismo de nitrogênio em Canavalia ensiformis, em resposta ao nitrato, durante o período reprodutivo. A dose de nitrato fornecida mudou as concentrações de udeídeos exportados via xilema, enquanto alterações no estádio de desenvolvimento mostrou influenciar a forma de ureídeo exportado via xilema. Considerando o nível de ureídeos como um indicador do status da fixação biológica, é possível dizer que a fixação do nitrogênio pode ter sido afetada na presença do nitrato em $C$. ensiformis.

\section{ACKNOWLEDGEMENTS}

The authors acknowledge the support given to this work by the Fundação de Amparo a Pesquisa do Estado de São Paulo (FAPESP-Brazil, Grant No. 02/02536-0). L.S.C. and R.A.A. received a graduate scholarship and research fellowship from FAPESP (01/03462-8) and Conselho Nacional de Desenvolvimento Científico e Tecnológico (CNPq-Brazil), respectively.

\section{REFERENCES}

Atkins, C.S.; Fernando, M.; Hunt, S. and Layzell, D.B. (1992), A metabolic connection between nitrogenase activity and the synthesis of ureides in nodulated soybean. Physiologia Plantarum, 84, 441-447.

Azevedo, R.A.; Arruda, P.; Turner, W.L. and Lea, P.J. (1997), The biosynthesis and metabolism of the aspartate derived amino acids in higher plants. Phytochemistry, 46, 395-419.

Azevedo, R.A.; Lancien, M. and Lea, P.J. (2006), The aspartic acid metabolic pathway, an exciting and essential pathway in plants. Amino Acids, 30, 143162.

Azevedo, R.A.; Lea, P.J.; Damerval, C.; Landry, J.; Bellato, C.M.; Meinhardt, L.W.; Le Guilloux, M.; Delhaye, S.; Varisi, V.A.; Gaziola, S.A.; Gratão, P.L.; Toro, A.A. (2004), Regulation of lysine metabolism and endosperm protein synthesis by the opaque- 5 and opaque-7 maize mutations. Journal of Agricultural and Food Chemistry, 52, 4865-4871.

Brennecke, K.; Souza-Neto, A.J.; Lugli, J.; Lea, P.J. and Azevedo, R.A. (1996), Aspartate kinase in the maize mutants Ask1-LT19 and opaque-2. Phytochemistry, 41, 707-712.

Camargos, L.S.; Aguiar, L.F. and Azevedo, R.A. (2006), Site of nitrate reduction in Jack bean (Canavalia ensiformis) changes from leaf to root during development. New Zealand Journal of Crop and Horticultural Science, 34, 131-137.

Camargos, L.S.; Aguiar, L.F. and Azevedo, R.A. (2004), Variation in the amino acid concentration during development of Canavalia ensiformis. Biologia Plantarum, 48, 309-312.

do Amarante, L.; Lima, J.D. and Sodek, L. (2006), Gorwth and stress conditions cause similar changes in xylem amino acids for different legume species. Environmental and Experimental Botany, 58, 123129.

Ferreira, R.R.; Meinhardt, L.W. and Azevedo, R.A. (2006), Lysine and threonine biosynthesis in sorghum seeds: characterization of aspartate kinase and homoserine dehydrogenase isoenzymes. Annals of Applied Biology, 149, 77-86. 
Filippi, S.B.; Azevedo, R.A.; Sodek, L. and Mazzafera, P. (2007), Allatoin has a limited role as nitrogen source in cultured coffee cells. Journal of Plant Physiology, 164, 544-552.

Gaiad, S.; Rakocevic, M. and Reissmann, C.B. (2006), $\mathrm{N}$ sources affect growth, nutrient content, and net photosynthesis in mate (Ilex paraguariensis St. Hil.). Brazilian Archives of Biology and Technology, 49, 689-697.

Garcia, J.S.; Gratão, P.L.; Azevedo, R.A. and Arruda, M.A.Z. (2006), Metal contamination effect on sunflower (Helianthus annuus L.) growth and protein expression in leaves during development. Journal of Agricultural and Food Chemistry, 54, 8623-8630.

Herridge, D.F.; Palmer, B.; Nurhayati, D.P. and Peoples, M.B. (1996), Evaluation of the xylem ureide method for measuring N2 fixation in six tree legume species. Soil Biology and Biochemistry, 28, 281-289.

Huyanate, R.A.R.; Thomaz, M.C.; Kronka, R.N.; Fraga, A.L.; Scandolera, A.J. and Budiño, F.E.L. (2006), Effect of adding macro and micro minerals in pig feces fed diet with different levels of probiotic. Brazilian Archives of Biology and Technology, 49, 385-392.

Kingston-Smith, A.H.; Bollard, A.L. and Minchin, F.R. (2006), The effect of nitrogen status on the regulation of plant-mediated proteolysis in ingested forage; an assessment using non-nodulating white clover. Annals of Applied Biology, 149, 35-42.

Landry, J. and Delhaye, S. (2007), Influence of genotype and texture on zein content in endosperm of maize grains. Annals of Applied Biology, 151, 349356.

Lea, P.J. and Azevedo, R.A. (2006), Nitrogen use efficiency. 1. Uptake of nitrogen from the soil. Annals of Applied Biology, 149, 243-247.

Lea, P.J. and Azevedo, R.A. (2007), Nitrogen use efficiency. 2. Amino acid metabolism. Annals of Applied Biology, 151, 269-275.

Lea, P.J.; Sodek, L.; Parry, M.A.J.; Shewry, P.R. and Halford, N.G. (2007), Asparagine in plants. Annals of Applied Biology, 150, 1-26.
Medici, L.O.; Azevedo, R.A.; Smith, R.J. and Lea, P.J. (2004), The influence of nitrogen supply on antioxidant enzymes in plant roots. Functional Plant Biology, 31, 1-9.

Medici, L.O.; Machado, A.T.; Azevedo, R.A. and Pimentel, C. (2003), Glutamine synthetase activity, relative water content and water potential in maize submitted to drought. Biologia Plantarum, 47, 301304.

Medici, L.O.; Pereira, M.B.; Lea, P.J. and Azevedo, R.A. (2005), Identification of maize lines with contrasting responses to applied nitrogen. Journal of Plant Nutrition, 28, 903-915.

Peoples, M.B.; Atkins, C.A.; Pate, J.S.; Chong, K.; Faizah, A.W.; Suratmini, P.; Nurhayati, D.P.; Bagnall, D.J. and Bergersen, F.J. (1991), Reevaluation of the role of ureides in the xylem transport of nitrogen in Arachis species. Physiologia Plantarum, 83, 560-567.

Perin, A.; Santos, R.H.S.; Urquiaga, S.; Guerra, J.G.M. and Cecon, P.R. (2004), Phytomass yield, nutrients accumulation and biological nitrogen fixation by single and associated green manures. Pesquisa Agropecuaria Brasileira, 39, 35-40.

Pompeu, G.B.; Vendemiatti, A.; Gratão, P.L.; Gaziola, S.A.; Lea, P.J. and Azevedo, R.A. (2006), Saccharopine dehydrogenase activity in the highlysine opaque and floury maize mutants. Food Biotechnology, 20, 55-64.

Santos, J.M.G.; Moreira, I. and Martins, E.N. (2006), Lysine and metabolyzable energy requeriments of lactating sows for subsequent reproductive performance. Brazilian Archives of Biology and Technology, 49, 575-581.

Varisi, V.A.; Medici, L.O.; van der Meer, I.; Lea, P.J. and Azevedo, R.A. (2007), Dihydrodipicolinate synthase in opaque and floury maize mutants. Plant Science, 173, 458-467.

Vogels, G.D. and Van Der Drif, T.C. (1970), Differential analyses of glyoxylate derivates. Analytical Biochemistry, 33, 143-157. 